\title{
Gender dan Orientasi Seksual Waria: Faktor Pembentukannya pada Lingkungan
}

\section{Harpan Reski Mulia}

UIN Sunan Kalijaga Yogyakarta

harpanreskimulia@gmail.com

Article Information:

Received 14 September 2020

Revised 21 January 2021

Accepted 26 January 2021

Keywords:

Family roles; Gender; Sexual orientation; Transgender

Kata Kunci:

Gender; Orientasi seksual; Peran keluarga; Waria
This paper specifically explores the role of the family in shaping the gender identity of shemale and how the gender of shemale refers to their sexual orientation. This research conduct in Yogyakarta with a qualitative research method. Data obtained by using interviews, observation, and documentation. The subjects in this study were six transgender people. The research data was then analyzed by referring to Miles and Huberman's opinion, namely data reduction, data presentation, and conclusions. This study shows that the family has a role in shaping the identity of transgender women, both indirectly and indirectly, namely by giving toys that are not by gender, providing bullying with the call of transgender. The family's direct role is to direct children to become transgender women because "Banci" people perceive them as sacred people in some cultures. This study also shows that sexually transgender women are men, while their sexual orientation likes men. Transgender women are categorized as homo because they understand that they have a female soul to carry out roles as women in all respects, including sexual relations.

Abstrak
Tulisan ini secara khusus mengekplorasi peran keluarga dalam membentuk identitas gender waria dan bagaimana gender waria mengarah kepada orientasi seksual mereka. Penelitian ini dilakukan di Yogyakarta dengan metode penelitian kualitatif. Data diperoleh dengan menggunakan wawancara, observasi dan dokumentasi. Subjek dalam penelitian ini berjumlah enam orang waria, kemudian data penelitian ini dianalisis dengan merujuk pendapat Miles dan Huberman yakni reduksi data, penyajian data dan membuat kesimpulan. Penelitian ini menunjukkan bahwa keluarga mempunyai peran dalam membentuk identitas waria baik secara tidak langsung dan secarang langsung. Secara tidak langsung dengan memberikan mainan yang tidak sesuai dengan gender, memberikan bullying dengan panggilan banci. Peran keluarga secara langsung yaitu dengan mengarahkan anak untuk menjadi waria, karena dalam beberapa kebudayaan waria dianggap sebagai seseorang yang sakral. Selanjutnya penelitian ini juga menunjukkan bahwa secara seksual waria adalah seorang laki-laki, sedangkan secara orientasi seksual mereka menyukai kepada laki-laki juga sehingga waria dikategorikan sebagai homoseksual. Hal ini karena mereka memahami bahwa mereka 
adalah laki-laki yang mempunyai jiwa perempuan, sehingga dalam segala hal mereka melakukan peran sebagai perempuan termasuk hubungan seksual.

\section{PENDAHULUAN}

Kajian gender dan seksualitas memang tidak pernah sunyi dari ruang diskusi, terutama setelah Sigmun Freud pada abad ke-19 memberikan analisis yang lebih luas tentang seksualitas (Foucault, 2014). Menyesuaikan gender dan orientasi seksual kerap menjadi tema dalam perdebatan yang tidak pernah habisnya, mulai dari masyarakat awam hingga sarjanawan. Perbincangan tersebut memperlihatkan ada kelompok masyarakat dimana gender dan seksualitasnya bertolak belakang atau bertentangan yang disebut dengan kelompok Lesbian, Gay, Biseksual, Trangender dan Queer (LGBTQ).

Tulisan ini berfokus kepada waria (transgender), karena secara definitif lebih mudah dikenali yang berimplikasi kepada lebih mudahnya mendapatkan subjek penelitian. Selanjutnya secara definisi, waria yang dimaksudkan dalam tulisan ini merujuk kepada pendapat Tomm Boellstroff yaitu mempunyai empat kriteria. Pertama, secara seks mereka mengakui mempunyai penis. Kedua, mereka yang mengakui mempunyai jiwa perempuan. Ketiga, mereka yang berdandan sebagaimana layaknya seorang perempuan dan keempat, mereka yang mempunyai orientasi seksual kepada lakilaki (Boellstorff, 2005).

Kompleksitas permasalahan waria telah banyak menghadirkan hasil penelitian, diantaranya tinjauan literatur yang dilakukan oleh Misri Gozan dengan tujuan untuk mengetahuai kromosom yang bertanggungjawab terhadap orientasi seksual waria. Gozan menuwai kesimpulan bahwa tidak ada data yang kuat tentang orientasi seksual waria disebabkan faktor genetik (Gozan, 2016, 2017). Jika diatas dengan sudut pandang genetik, maka penelitian yang dilakukan oleh Maria Juscinaide Henrique Alves, dkk (2016) dalam menganalisisis terbentuknya orientasi seksual waria adalah melalui lensa sosiologis. Alves dkk memberikan kesimpulan bahwa orientasi seksual waria kepada laki-laki disebabkan karena pengalaman pertamanya ketika melakukan hubungan seksual dengan sesama jenis, sehingga ketika dewasa hasrat untuk melakukan hubungan seksual sejenis datang kembali. Berbeda dengan penelitian Alves tersebut, Salman Darmawan dan Suardi (2015) menemukan bahwa pembentukan identitas gender waria di kecamatan Bulukumpa adalah karena waria menganggap bahwa identitas waria yang mereka miliki merupakan takdir dan dengan menjadi waria mereka lebih bisa mengaktualisasikan diri mereka.

Selain beberapa penelitian di atas, penelitian yang memberi kontribusi lebih pada penelitian ini adalah penelitian Dewi Rokhmah (2015). Penelitian tersebut memperlihatkan bahwa sebagian besar subjeknya menjadi waria karena pola asuh koersif dan sebagian kecil subjeknya kehilangan sosok atau figur ayah dalam memberikan pendidikan. Akan tetapi, penelitian Rokhmah tersebut tidak terfokus dalam menggali pola asuh tersebut, karena dilain pihak, ia juga bertujuan untuk melihat pengaruhnya terhadap perilaku seksual beresiko HIV/Aids. 
Kemudian, Penelitian yang juga memberi kontribusi dalam penelitian ini adalah penelitian Aprilia Dewi Nurlitasari, dkk (2019). Penelitian tersebut dilakukan dengan menyebar kuesioner kepada 60 orang waria yang tujuannya adalah untuk mengetahui hubungan peran keluarga dan lingkungan sosial dengan pembentukan identitas waria. Hasil dari penelitian mereka menunjukkan bahwa, peran keluarga berhubungan dengan identitas warai dengan nilai p-value 0,048, demikian juga lingkungan sosial mempunyai hungan signifikan dengan identitas waria dengan nilai $p$-value 0,024 .

Beranjak dari beberapa penelitian di atas, tampaknya bahwa ekplorasi tentang bagaimana lingkungan keluarga dalam membentuk gender dan orientasi seksual waria belum ada. Untuk mengisi kekosongan tersebut penelitian ini secara khusus akan mengkaji pembentukan identitas waria ditinjau dari faktor keluarga, fase-fase dalam pembentukan identitas gender waria dan bagaimana gender waria mengarah kepada orientasi seksual mereka. Peneliti berargumen bahwa keluarga mempunyai peran dalam pembentukan gender waria, sebagaimana lingkungan sosial memberi pengaruh kepada seseorang dan lingkungan sosial yang pertama adalah keluarga.

\section{METODE}

Penelitian ini menggunakan metode kualitatif untuk mengeksplorasi tentang peran keluarga dalam membentuk identitas gender waria, dan bagaimana gender waria mengarah kepada orientasi seksual. Adapun subjek dalam penelitian ini berjumlah enam orang waria, yakni dengan menggunakan metode penarikan subjek teknik snowbal (bola salju), dimana subjek pertama yang peneliti kenal adalah satu orang waria. Kemudian, peneliti meminta agar mencarikan subjek-subjek lain (Saleh, 2017). Pada akhirnya, ketika data yang didapat telah jenuh ditandai dengan jawaban dari subjek yang sama atau berulang walaupun dengan redaksi yang berbeda, maka terkumpul sebanyak enam orang subjek. Perlu peneliti sampaikan, subjek di sini hanya disebutkan dengan inisial (yakni: IN, SR, $\mathrm{AK}, \mathrm{RM}, \mathrm{RR}$, dan $\mathrm{NH}$ ) karena untuk menjaga asas kerahasiaan subjek dan perjanjian yang peneliti lakukan dengan subjek sebelum mengambil data.

Teknik pengumpul data yang digunakan adalah dengan wawancara, observasi dan dokumentasi. Wawancara yang dilakukan adalah dengan semi terstruktur dengan tujuan agar subjek lebih tebuka dan memunculkan pandangan-pandangan subjek itu sendiri, sedangkan observasi dilakukan ketika sedang melakukan wawancara, yakni dengan mempelajari bahasa tubuh, emosi dan lain sebagainya dengan catatan berkaiatan dengan penelitian. Adapun dokumentasi, peneliti dapatkan kumpulkan baik dokumen cetan maupun dokumen online yang dinilai sesuai dengan penelitian ini (Creswell, 2017).

Analisis data pada penelitian ini merujuk pendapat Miles dan Huberman yaitu, sejak pengumpulan data secara interaktif dan berlangsung secara terus-menerus sampai tuntas dan datanya sudah jenuh. Kegiatan analisis selama pengumpulan data dimaksudkan agar temuan data lebih terfokus, kemudian penyusunan temuan sementara dan membuat rencana pengumpulan data seterusnya, serta mengembangkan pertanyaan- 
pertanyaan analitik dan menetapkan sasaran pengumpulan data selanjutnya. Karena data yang diperoleh dari lapangan semakin banyak, komplek dan rumit, maka perlu dilakukan dilakukan analisis data melalui reduksi data. Setelah data direduksi, langkah selanjutnya adalah menyajikan data. Terakhir menarik kesimpulan atau verifikasi data yakni dengan triangulasi data baik teknik maupun sumber data.

\section{PAPARAN HASIL}

Berdasarkan penarikan subjek dengan teknik snowball, maka didapat enam orang waria yang menjadi subjek dalam penelitian, yaitu:

Tabel 1. Subjek Penelitian

\begin{tabular}{cccccc}
\hline \multirow{2}{*}{ No } & \multirow{2}{*}{ Subjek } & \multirow{2}{*}{ Umur } & Pekerjaan & \multicolumn{2}{c}{ Hubungan dengan Keluarga } \\
& & & Baik & Tidak Baik \\
\hline 1 & IN & 36 Tahun & Pengamen & $\sqrt{ }$ & \\
2 & SR & 35 Tahun & Wirausaha & $\sqrt{ }$ & \\
3 & AK & 42 Tahun & Wirausaha & $\sqrt{ }$ & \\
4 & RM & 58 Tahun & Pengamen & $\sqrt{ }$ & $\sqrt{ }$ \\
5 & RR & 28 Tahun & PSK & & \\
6 & NH & 34 Tahun & PSK & & \\
\hline
\end{tabular}

Berdasarkan hasil penelitian, maka didapatkan tiga temuan yang menjadi sentral hasil penelitian ini, yaitu:

Tabel 2. Peran Keluarga dalam Pembentukan Identitas Gender Waria

\begin{tabular}{ll}
\hline \multicolumn{1}{c}{ Hasil } & \multicolumn{1}{c}{ Item } \\
\hline Secara Tidak Langsung & 1. Memberikan mainan yang tidak sesuai dengan gender \\
& 2. Tidak mengontrol pergaulan anak \\
3. $\begin{array}{l}\text { Memanggil anak dengan sebutan banci baik untuk } \\
\text { memberikan punisment atau karena memang melihat anak } \\
\text { berbeda dengan yang lainnya }\end{array}$ \\
\hline Secara Langsung & 1. $\begin{array}{l}\text { Mengarahkan anak untuk menjadi waria karena nilai } \\
\text { kebudayaan }\end{array}$ \\
\hline
\end{tabular}

Tabel 2 di atas, memperlihatkan tentang peran keluarga dalam membentuk identitas gender waria baik secara langsung maupun tidak langusung. Kemudian, setelah identitas gender waria telah dibentuk dalam lingkungan keluarga, maka waria akan menjalani tiga fase untuk dapat secara terbuka menyatakan identitas gendernya.

Tabel 3. Fase pembentukan identitas waria

\begin{tabular}{ll}
\hline \multicolumn{1}{c}{ Hasil } & \multicolumn{1}{c}{ Tanda } \\
\hline Fase keraguan & $\begin{array}{l}\text { Ditandai dengan anak mencari informasi tentang identitasnya, karena } \\
\text { merasa berbeda dengan orang lain }\end{array}$ \\
Fase menyadari & $\begin{array}{l}\text { Ditandai dengan mencoba-coba untuk berpakaian seperti layaknya } \\
\text { perempuan tapi hanya terbatas dalam lingkupnya sendiri seperti di } \\
\text { dalam kamar }\end{array}$ \\
& $\begin{array}{l}\text { Ditandai dengan memberikan pengakuan kepada keluarganya akan } \\
\text { identitas gendernya dan mulai berdandan dalam melakukan aktifitas } \\
\text { di luar rumah }\end{array}$ \\
\hline
\end{tabular}

$\mathbf{5 8}$ | Journal An-Nafs: Kajian Penelitian Psikologi, Vol. 6 No. 1 Juni 2021 
Dari tabel 3 tersebut, maka waria secara gender meniru dan malakukan aktifitas sebagaimana layaknya perempuan. Hasil penelitian selanjutnya menunjukkan, bahwa implikasi dari gender waria yang beraktifitas sebagai perempuan terhadap orientasi seksual mereka.

Tabel 4. Gender dan Orientasi Seksual Waria

Kepercayaan waria akan identitas $\quad$ Implikasi kepercayaan identitas gender terhadap mereka

1. Waria terlahir dengan jenis kelamin laki-laki

2. Waria mempunyai jiwa perempuan orientasi seksual

Dengan kepercayaan bahwa mereka adalah seseorang yang memiliki jiwa perempuan dan terlahir pada tubuh laki-laki, maka orientasi seksual mereka diarahkan kepada laki-laki. Tujuan dari pengarahan tersebut yaitu agar menambah keyakinan dalam diri mereka, bahwa mereka secara jiwa adalah perempuan

Tabel 4 di atas, merupakan temuan tentang bagaimana identitas gender waria dibangun atas dasar kepercayaan akan konsep diri mereka. Atas dasar kepercayaan tersebut, maka mereka menilai bahwa melakukan aktivitas seksual dengan laki-laki merupakan hal yang wajar. Selain itu tujuannya juga yaitu agar mereka lebih meyakiankan diri bahwa secara jiwa memang seorang perempuan.

\section{PEMBAHASAN}

\section{Peran Keluarga dalam Pembentukan Identitas Gender Waria}

Seseorang menjadi waria tidak bisa lepas dari sebuah perjalanan panjang, mulai perkembangan masa anak-anak sampai dewasa. Perlu peneliti tekankan, bahwa pembahasan ini bukan dengan pengertian bahwa peneliti meniadakan pengaruh dari faktor lain seperti lingkungan, genetik dan lain sebagianya. Akan tetapi, peneliti di sini hanya melihat dari peran keluarga dalam membentuk identitas waria, karena nilai yang pertama didapatkan seorang anak adalah dari apa yang dia pelajari pada lingkungan keluarga. Lingkungan keluarga pada penelitian ini menjadi temuan sentral dalam pembentukan identitas gender waria. Dalam hal ini, peneliti menemukan peran keluarga secara tidak langsung dan langsung dalam membentuk identitas gender waria.

Peran keluarga tidak secara langsung secara umum, subjek dalam penelitian ini menyatakan bahwa mereka telah menyadari akan identitas gender mereka sebagai seorang waria sejak kecil. Hal ini disebabkan karena dua alasan, Pertama karena keluarga mereka terutama ibu selalu membelikan mainan-mainan perempuan seperti boneka, alatalat masak dan lain sebagainya. Kedua, karena mereka ketika kecil lebih suka bermain dengan anak perempuan seusia mereka.

Kedua alasan di atas menjadi dasar bagi waria yang mendefinisikan diri mereka waria sejak kecil, walaupun pada saat kecil mereka mereka belum tahu apa itu waria. Akan tetapi sejak kecil mereka telah merasakan perbedaan yang kentara dengan temanteman laki-laki sebayanya. Perbedaan ini diungkapkan subjek SR, AK dan IN bahwa 
mereka ketika bermain dengan teman sebaya perempuan merasa nyaman dan enjoy, berbeda ketika mereka bermain dengan anak laki-laki sebayanya, mereka seolah mempunyai ketertarikan seperti ketertarikan laki-laki kepada perempuan.

Lebih lanjut, semua subjek memberikan penegasan tentang keberadaan mereka sebagai waria sejak kecil adalah dikarenakan mereka terlahir dengan biologis laki-laki (penis), akan tetapi mereka mempunyai ketertarikan seksual kepada laki-laki. Hal ini sejalan dengan yang diungkapkan Mulia (2020), bahwa seseorang anak yang mempunyai jiwa waria terlihat dari kegemaran mereka, seperti lebih senang dengan mainan perempuan dan juga lebih akrab dengan perempuan. Disinilah letak, dimana peran orang tua dalam mengarahkan gender seorang anak berperan penting, jika orang tua membiarkan maka kemungkinan anak menjadi waria ketika dewasa akan lebih besar, demikian pula sebalikanya.

Berkenaan dengan pemberian kepada anak laki-laki mainan yang tidak sesuai dengan gendernya seperti boneka, di sinilah titik dimana peran orang tua dalam mengarahkan gender seorang anak atau seperti yang diungkapkan oleh Reiss dan Lee (Dalam Rokhmah 2017) bahwa keluarga sebagai institusi memberikan sumbangan besar terhadap perubahan sosial bagi anak dalam kehidupan sosialnya. Dengan pengertian bahwa, hal kecil yang dianggap tidak akan mempengaruhi sikap dan perilaku anak ketika dewasa, justru menjadi penguat (reinforcement) dalam bersikap dan bertindak baik itu nilai positif atau nilai negatif.

Ketiga sabjek yang menunjukkan bahwa pada masa kecil, mereka lebih senang bermain dengan perempuan, ketika ditelusuri lebih dalam adalah mereka yang tidak mendapatkan pengawasan dari dari orang tua, seperti yang diungkapkan oleh SR (35 Tahun) bahwa pekerjaan ayahnya sebagai pelayar yang pulang satu kali dalam enam bulan sedang ibunya adalah seorang pedagang, membuat dirinya memang tidak pernah dipantau dengan siapa dia bergaul, sehingga dia tidak pernah mendapatkan pendidikan dari orang tuanya terutama berkaitan dengan pendidikan seks. Hal ini membuktikan bahwa pengawasan dari orang tua dan pemberian pendidikan seks merupakan sesuatu yang penting dalam upaya mengantisipasi terjadinya perilaku menyimpang LGBT (Wahyuni, 2018).

Pemberian mainan yang tidak sesuai dengan gender seperti boneka dan tidak adanya pengawasan orang tua terhadap pergaulan anak, merupakan salah satu peran keluarga dalam pembentukan identitas gender waria yakni secara tidak langsung, karena seperti yang diungkapkan Sinyo (2014) bahwa pola asuh termasuk pengawasan merupakan hal yang sangat dominan dalam membentuk dan memperkuat karakter anak yang nantinya akan dia bawa sampai dewasa. Selanjutnya selain dua peran keluarga tersebut, pembulyyan secara verbal oleh keluarga kepada anak dengan menyebutnya banci atau bencong ("Banci" atau "Bencong" adalah untuk menghinakan, maka kategori ini dapat dikatakan sebagai bullying, Lihat: Boellstorff 2005:28) menjadi salah satu faktor dalam menegaskan dirinya merupakan waria sejak kecil.

60 | Journal An-Nafs: Kajian Penelitian Psikologi, Vol. 6 No. 1 Juni 2021 
Subjek AK memberikan penjelasan bahwa dia kerap mendapatkan Bulyying dengan sebutan "Banci" atau "Bencong" dari keluarga terutama ayah ketika dimarahi. Dengan pengertian bahwa hal tersebut akan memberikan penguatan bahwa dia berbeda dengan yang lain (laki-laki dan perempuan) dalam kehidupannya pada masa-masa selanjutnya. Sejalan dengan subjek AK, subjek IN juga pertama kali mendengarkan istilah gender lain (selain laki-laki dan perempuan) dari ayahnya. Subjek mengungkapkan ayahnya mengungkapkan bahwa anaknya lengkap ada laki-laki, perempuan dan banci.

Sebagaimana kasus subjek AK dan IN di atas, mereka mengungkapkan bahwa pada tahap selanjutnya mereka mencari tahu makna dari kata "banci" tersebut baik melalui koran, majalah dan internet dan kemudian menyadari bahwa mereka memang berbeda dari laki-laki dan perempuan sebagaimana yang diucapkan oleh orang tua mereka. Hal ini sejalan dengan pendapat Kifrawi (2016) bahwa pada usia dini tahap yang pertama yang dilalui oleh anak aadalah tahap transformasi nilai, yakni orang tua (orang dewasa) mentransformasi nilai baik atau buruk melalui verbal. Alhasil, ketika orang tua mengeluarkan kata yang baik maka akan ditiru oleh anak, demikian pula sebaliknya dan pelaku bullying sering berasal dari keluarga (Suendri, 2016).

Jika pembahasan di atas peran keluarga secara tidak langsung dalam pembentukan idenititas gender waria, maka ada kasus dimana keluarga dinilai secara langsung mengarahkan anak menjadi waria. RM (58 Tahun) adalah subjek yang berasal dari Makassar, subjek menuturkan bahwa memang dia merupakan seorang waria (atau dalam kebudayaan bugis biasa disebut bissu), sehingga ia memang diarahkan kepada gender waria. Hal ini memang mungkin terjadi karena melihat subjek ini dibesarkan dalam kelurga bugis yang memang diakui keberadaan gender waria dengan sebutan bissu dan calabai (Nurfadillah, 2019).

Ungkapan Boellstroff (2005) bisa menjadi alasan kuat kenapa keluarga subjek mengarahkannya menjadi seorang bissu yaitu karena pada kebudayaan bugis, selain diakui akan kehadirannya, bissu juga mempunyai posisi penting dalam adat mereka seperti pada musim panen, pernikahan, dan lain sebagainya. Selain Bissu, dalam kebudayaan Bugis juga dikenal dengan sebutan Calabai, dimana calabai dalam kebudayaan bugis merupakan seorang laki-laki yang berpenampilan laiknya perempuan terutama pada saat upacara pernikahan. Calabai menjadi petugas penting dalam acara pernikahan, yaitu mulai dari dekorasi pelaminan, pakaian-pakaian pengantin hingga urusan dapur atau urusan persediaan makanan (Mulia, 2020).

Bukan hanya dalam kebudayaan Bugis, dalam budaya Ponorogo juga didapati dimana gemblak (laki-laki muda yang berumur sekitar 8-16 tahun) merupakan sosok yang dijadikan istri oleh warok termasuk dalam aktivitas seksual, karena warok dilarang berhubungan seksual dengan wanita untuk mempertahankan kesaktiannya (Boellstorff, 2005). Berkenaan dengan kebudayan inilah kemudian Sinyo (2014) mengungkapkan bahwa tidak bisa dipungkiri budaya atau adat istiadat dapat mempengaruhi perkembangan 
anak, demikian pula budaya yang dapat mempengaruhi pembentukan kepada orientasi sesama jenis.

Dilain pihak, Yusran (2018) mengatakan bahwa bissu tidak bisa disamakan dengan waria. Menurutnya, bissu hadir dalam kebudayaan bugis sebagai sosok yang suci dan sakral, patuh terhadap agama dan tidak berpenyakit secara sosial dan seksual. Hemat penulis, setidaknya karena sejak abad ke-16 kebanyakan bissu melakukan aktifitas seksual dengan laki-laki dan juga karena bissu ketika melakukan upacara ritual mengkombinasikan sifat laki-laki dan perempuan (Boellstorff, 2005), maka bissu pada kebudayaan Bugis dapat dikategorikan sebagai waria. Dengan demikian, pembahasan ini memberikan penegasan bahwa ketika subjek RM diarahkan untuk menjadi waria, maka hal itu karena orang tua subjek berkeinginan agar subjek menjadi seorang yang suci sebagimana diakui dalam kebudayaan Bugis.

Dari data dan pembahasan di atas, maka dapat dinyatakan bahwa keluarga ikut berperan dalam mengarahkan dan membentuk anak menjadi seorang waria baik secara tidak langsung maupun secara langsung. Secara tidak langsung seperti memberikan mainan kepada anak yang tidak sesuai dengan gendernya, tidak mengontrol pergaulan anak dan ucapan baik sebagai bahan untuk bercanda atau sebagai ungkapan bullying. Kemudian, pada sub bahasan berikut akan mendiskusikan fase subjek menjadi waria seutuhnya.

\section{Menjadi Waria Seutuhnya}

Sebelum lebih jauh, perlu penulis jelaskan bahwa yang penulis maksud dengan menjadi waria seutuhnya adalah fase-fase yang mereka lalui untuk membuka diri pada ranah publik ditandai dengan berpakaian atau berdandan sebagaimana laiknya seorang perempuan. Mengapa ditandai dengan berdandan seperti perempuan yang menjadi pertanda bahwa mereka telah membuka diri pada ranah publik. Hal ini dikarenakan dua alasan, pertama meminjam ungkapa Boellstroff bahwa berdandan merupakan kebahagiaan tersendiri bagi mereka, tidak seorangpun waria yang tidak berdandan dan berdandan menjadi pembenda di antara waria dan gay. Kedua, karena sumber penolakan masyarakat terhadap waria adalah ketika mereka berdandan seperti perempuan (Arfanda \& Anwar, 2015).

Sebagaimana pada umumnya, waria tidak akan langsung menjadi seorang waria sejak kecil, artinya mereka melalui beberapa proses dalam meyakinkan diri bahwa mereka seorang waria. Demikan pula subjek dalam penelitian ini, semua subjek mengatakan bahwa mereka melewati beberapa fase hingga mereka yakin dengan keputusan mereka sebagai waria dan berdandan seperti layaknya perempuan.

Temuan dalam penelitian ini menunjukkan bahwa secara keseluruhan mereka mengalami tiga fase, yaitu: fase keragu-raguan (ambiguitas). Waria yang merasa telah memiliki jiwa perempuan sejak dini dapat dilihat dari kegemaran mereka (biasanya lebih suka bermain boneka) dan pergaulan mereka (lebih senang berteman dengan perempuan).

62 | Journal An-Nafs: Kajian Penelitian Psikologi, Vol. 6 No. 1 Juni 2021 
Dari hal tersebut, para waria sejak dini sudah kerap mendapatkan bullying dari temantemannya, misalnya digelari dengan sebutan banci (melayu), wandu (jawa), leklap (mandailing), dan lain sebagainya. Tidak hanya dari teman-temannya, ketika tanda-tanda yang menunjukkan seseorang itu adalah waria, pihak keluarga juga sering memberikan bullying yang serupa. Akibat dari perlakuan negatif tersebut, kemudian tertanam dalam alam bawah sadar mereka bahwa mereka adalah perempuan yang terlahir di dalam fisik laki-laki.

Pada fase ini, waria masih mempertanyakan akan identitas mereka karena berbeda dengan orang pada umumnya. Gejolak akan identitas ini, terus berlangsung dan biasanya hal ini berlangsung padda sekitaran umur 12-18 tahun, walaupun pada beberapa kasus menurut Dewi Rokhmah (2017), bisa terjadi pada usia 6-11 tahun. Ihwal ini akan terus terjadi, sampai mereka mendapatkan informasi yang menurut mereka sesuai dengan yang mereka rasakan, seperti yang diuangkapkan subjek AK dan SR di atas.

Fase menyadari (signification). Pada fase selanjutnya, setelah waria mendapatkan informasi tentang identitas gender mereka, maka waria kemudian mulai menyadari bahwa mereka terlahir dengan jenis kelamin laki-laki. Akan tetapi, secara perilaku dan sifat, mereka mereka lebih condong kepada perempuan. Pada tahap ini, bagi waria yang mempunyai kakak perempuan atau adik perempuan, mereka lalu mencoba untuk menggunakan pakaian dan berdandan layaknya perempuan.

Adapun subjek yang tidak mempunyai kakak perempun agar bisa berdandan layak perempuan mereka pergi ke rumah teman-teman warai. Subjek yang seperti ini adalah mereka yang mencari informasi tentang identitas itu dari sesama waria. Pada tahap inilah kemudian ketika mencari akan identitas dari sesama waria, mereka kemudian mengarah untuk melakukan hubungan seksual dengan laki-laki. Hal ini sejalan dengan pendapat Dewi Rokhmah (2017), bahwa pada tahap menyadari ini para waria mendapatkan pengalaman pertama dalam melakukan hubungan seksual dengan laki-laki yang kemudian memberi efek pada masa-masa perkembangannya dalam menegaskan identitas mereka.

Fase membuka diri (coming-out). Fase terakhir waria dalam pembentukan identitas ini adalah coming-out. Proses ini terjadi setelah subjek melawati fase kebimbangan dan fase menyadari, fase ini menurut Rohmah terjadi pada waria yang berumur 18 tahun ke atas (Rokhmah, 2017). Ada dua gambaran yang diberikan subjek dalam menandakan coming-out ini, pertama adalah mereka mengakui kepada keluarga mereka bahwa mereka adalah waria, dan kedua adalah subjek berani memakai pakaian wanita atau berdandan dalam melakukan aktifitas pada ranah publik.

Selain itu, subjek yang peneliti temui mengungkapkan bahwa ketika mereka telah memberikan pengakuan kepada pihak keluarga, banyak dari pihak keluarga subjek kemudian memberikan perilaku diskriminatif baik secara fisik maupun secara verbal. Waria yang mendapatkan diskriminatif secara fisik seperti dipukul, biasanya mereka dapatkan dari ayah dan saudara laki-laki mereka. Adapun waria yang mendapatkan 
diskriminatif secara verbal, dominan didapatkan dari ibu atau saudara perempuan mereka. Selanjutnya, subjek yang mendapatkan perlakuan diskriminatif tersebut cenderung untuk melarikan diri dari kampungnya atau pergi merantau ke kota-kota yang direkomendasikan waria lainnya.

Di samping itu, temuan juga menunjukkan mereka yang mendapatkan diskriminasi secara fisik memilih untuk pulang ke rumah dalam jangka yang lebih lama atau bahkan belum pernah pulang setelah subjek lari dari rumah. Adapun subjek yang mendapatkan perlakuan diskriminatif secara verbal, tidak seorangpun diantara subjek yang mengatakan belum pernah pulang ke rumah setelah dia melarikan diri. Hanya saja satu diantara subjek tersebut mengatakan bahwa ketika dia pulang ke rumah dia tidak berdandan laikanya perempuan.

\section{Identitas Gender dan Orientasi Seksual Waria}

Setelah dua pembahasan di atas yakni tentang peran keluarga dalam pembentukan identitas gender waria dan pembahasan tentang menjadi waria seutuhnya, sub bab ini akan mendiskusikan bagaimana identitas gender waria mengarah kepada orientasi seksual mereka. Pemabahasan ini akan dimulai dari memberikan definisi gender dan seksualitas. Gender merupakan pembeda antara laki-laki dan perempuan yang dibangun oleh masyarakat terkait atribut yang seharusnya ditempelkan kepada laki-laki atau perempuan (Azisah dkk., 2016). Sementara itu, orientasi seksual adalah ketertarikan seseorang, baik secara fisik, mental, dan emosional, serta seksual pada jenis kelamin tertentu. Biasanya orientasi seksual ada empat kategori, yaitu: 1) heteroseksualitas, ketertarikan pada individu dari jenis kelamin lain; 2) homoseksualitas, ketertarikan pada individu dengan jenis kelamin yang sama; 3) biseksualitas, ketertarikan pada individu dari kedua jenis kelamin; 4) aseksualitas, tidak ada ketertarikan pada seks (Keirns dkk, 2016).

Ketika gender dipandang dari segi atribut yang seharusnya ditempelkan kepada seseorang, maka secara keseluruhan subjek dalam penelitian ini memakai atribut-atribut yang seharusnya dipakai oleh perempuan dalam kebudayaan Indonesia. Memakai rok, hijab/jilbab, daster, makeup, dan tidak jarang pula subjek dalam penelitian ini mengatakan bahwa mereka memakai bikini ketika hendak keluar, agar terlihat utuh seperti layaknya perempuan. Namun di sisi lain seperti yang telah diungkapkan di atas, subjek dalam hal ini tetap mengakui bahwa mereka terlahir sebagai seorang perempuan. Oleh karena itu, atribut yang dipakai oleh subjek bertentangan dengan biologis mereka, maka dalam hal ini mereka dikategorikan sebagai transgender.

Adapun berkenaan dengan orientasi seksual, keseluruhan subjek dalam penelitian ini menyatakan bahwa secara seksual mereka tertarik kepada laki-laki. Seperti yang dikatakan oleh subjek NH dengan tegas bahwa dinamakan seseorang sebagai waria kalau seseorang itu terlahir dengan alat kelamin laki-laki (penis), tetapi mempunyai jiwa perempuan dan berbeda dengan interseks. Bahkan menurut subjek RR yang berprofesi

64 | Journal An-Nafs: Kajian Penelitian Psikologi, Vol. 6 No. 1 Juni 2021 
sebagai PSK, waria lebih diuntungkan karena waria tidak akan hamil walaupun berhubungan tanpa pengaman karena waria tidak mempunyai rahim seperti perempuan.

Dari pernyataan beberapa subjek di atas, maka dalam hal ini waria secara biologis adalah laki-laki dan secara jiwa mereka mempunyai jiwa perempuan. Adapun terkait orientasi seksual dan identitas gender waria, semua subjek dalam penelitian ini menyatakan orientasi seksual mereka tertuju kepada laki-laki. Penegasan ini didapakan dari subjek RR, NH dan AK bahwa mereka sama sekali tidak mempunyai hasrat untuk melakukan hubungan seksual dengan perempuan dan atas alasan tersebut membuat semua subjek dalam penelitian ini mengatakan bahwa mereka tidak akan menikah dengan perempuan.

Subjek NH bahkan menegasan jika waria yang menikah dengan seorang perempuan, hanya karena desakan dari orang tua dan lingkungan sosial. Menurut pengalamannya yang mempunyai teman waria dan menikah dengan seorang perempuan, pernikahan tersebut tidak ada yang utuh atau bertahan lama. Ada yang suaminya mengaku dan ada yang karena istrinya mengetahui bahwa suaminya adalah waria. Hal ini senada dengan pendapat Sinyo (2016) bahwa orang Same Sex Attraction (temasuk waria) ditekan dari banyak sisi, yakni dari dalam diri berupa desakan hidup seperti orang heteroseksual dan dari luar sering mendapat pertanyaan kapan menikah. Bahkan menurut Fajar Sugianto (2015) banyak di antara LGBT yang akhirnya menikah secara hetero, akhirnya memilih untuk mempunyai "jajan" di luar yang berdampak lebih mudahnya penyebaran HIV dan AIDS dan akan memupuk prostitusi homoseksual.

Dari beberapa pernyataan subjek di atas, dipahami bahwa orientasi seksual waria dapat dikategorikan sebagai homoseksual. Boellstroff (2005) juga memberikan pernyataan bahwa bissu yang dijadikan sebagai dasar bahwa waria bukan produk baru di Indonesia, mempunyai orientasi seksual kepada laki-laki setidaknya sejak abad ke-16. Temuan dalam penelitian ini sedikit berbeda dengan penelitian Nursalam dan Suardi (2017), mereka mengatakan bahwa beberapa waria di Makassar kecamatan Panakkukang berkeinginan untuk menikah dengan perempuan sehingga bisa dikategorikan heteroseksual.

Hemat peneliti, pernyataan dari Nursalam dan Suardi tersebut adalah pernyataan yang tidak beralasan, karena merujuk tulisan Mutimmatul Faidah (2014) Faidah sendiri dalam tulisannya ketika mengidentifikasikan faktor penyebab seseorang menjadi waria, disebutkan bahwa empat dari lima subjeknya menjadi waria karena alasan pernah melakukan seksual dengan sesama jenis. Selain itu, terdapat kerancuan dalam tulisan ini, yaitu ketika Nurussalam dan Suardi membahas orientasi biseksual waria, mereka menyatakan bahwa waria itu termasuk pada kategori homoseksual, sementara biseksual dan homoseksual adalah jenis orientasi seksual yang berbeda.

Dari pemaparan di atas, identitas gender waria erat kaitannya dengan perilaku homoseksual. Secara biologis, mereka memang terlahir sebagai laki-laki, tetapi sifat dan 
jiwa mereka adalah perempuan. Mengingat orientasi seksual waria terhadap laki-laki, maka waria dalam hal ini termasuk dalam kategori homoseksual.

\section{SIMPULAN}

Dari hasil penelitian dan analisis di atas, maka dapat ditarik beberapa kesimpulan terkait permasalahan yang diajukan dalam pada latar belakang. Pertama, keluarga mempunyai peran dalam membentuk identitas waria baik secara tidak langsung dan secarang langsung. Adapun secara tidak langsung, penelitian ini menunjukkan bahwa keluarga memberikan main-mainan yang bertentangan antara seksual dan jenis kelamin mereka, ketidakadaan kotrol dari orang tua terhadap pergaulan anaknya dan keluarga ikut serta dalam memberikan bullying kepada anaknya dengan sebutan banci. Adapun peran keluarga secara langsung yaitu keluarga memang mengarahkan anak untuk menjadi waria, karena anggapan dalam kebudayaan bugis waria merupakan orang yang suci yang dapat menjadi perantara antara manusia dengan Tuhan.

Selanjutnya, waria dalam penelitian ini menunjukkan bahwa untuk mencapai seorang waria seutuhnya mereka menjalini tiga fase yaitu fase keraguan (ambiguisitas), fase menyadari (signification), dan fase membuka diri (coming-out). Temuan sentral kedua dalam penelitian ini yaitu bahwa secara orientasi seksual waria dikategorikan kepada homoseksual. Hal ini dikarenakan bahwa secara biologis waria adalah seseorang yang terlahir sebagai seorang laki-laki, sementara itu, secara orientasi seksual mereka menyukai laki-laki juga. Karena hal itu, kemudian secara gender mereka dinamakan sebagai transgender.

\section{DAFTAR PUSTAKA}

Alves, M. J. H., Parente, J. S., \& Albuquerque, G. A. (2016). Homosexual orientation in childhood and adolescence: Experiences of concealment and prejudice. Reprodução \& Climatério, 31(2), 68-75.

Arfanda, F., \& Anwar, S. (2015). Konstruksi Sosial Masyarakat Terhadap Waria. KRITIS : Jurnal Ilmu Sosial dan Ilmu Politik Universitas Hasanuddin, 1(1), 93102.

Azisah, S., Mustari, A., Himayah, \& Masse, A. (2016). Buku Saku: Kontekstualisasi Gender, Islam dan Dudaya. UIN Alauddin Press.

Boellstorff, T. (2005). The gay archipelago: Sexuality and nation in Indonesia. Princeton University Press.

Creswell, J. W. (2017). Research Design: Qualitative, Quantitative, and Mixed Methods Approaches 4th ed (A. Fawaid \& R. K. Pancasari, Penerj.). Pustaka Pelajar.

Faidah, M. (2014). Religiusitas dan Konsep diri Kaum Waria. Jurnal Studi Gender Indonesia, 4(1), Article 1.

Foucault, M. (2014). Ingin Tahu Sejarah Seksualitas. Yayasan Pustaka Obor Indonesia.

Gozan, M. (2016). Perilaku Homoseksual: Mencari Akar Faktor Genetik. Dalam D. Setiawan, Adrian, \& Suhairi (Ed.), Prosiding Seminar Internasional: Tinjauan terhadap Lesbian, Gay, Biseksual, dan Transgender (LGBT) dari Perspektif 
Hukum, Pendidikan dan Psikologi (hlm. 75-86). Program Pascasarjana STAIN Jurai Siwo Metro Lampung.

Gozan, M. (2017). Perilaku Homoseksual: Mencari Akar Pada Faktor Genetik. Nizham Journal of Islamic Studies, 4(1), 75-87.

Keirns, N. J., Strayer, E., Griffiths, H., Cody-Rydzewski, S., Scaramuzzo, G., Sadler, T., Vyain, S., Bry, J. D., Jones, F., \& OpenStax College. (2016). Introduction to sociology 2e. Openstax College.

Kifrawi. (2016). Penanaman Nikai Akhlak Pada Anak Usia Dini. Dalam Strategi Pendidikan Anak Usia Dini dalam Membina Sumber Daya Manusia Berkarakter (hlm. 84-98). Perdana Publishing.

Mulia, H. R. (2020). Pendosa!!! Kajian Stigma dan Identitas Kelompok Marginal Waria. Insan Cendekia Mandiri.

Nurfadillah. (2019). Pola Adaptasi Keagamaan dan Cultural Bissu Bugis di Masyarakat Segeri Kabupaten Pangkep Sulawesi Selatan. Dalam Otoritas Keagamaan, Politik dan Budaya Masyarakat Muslim (hlm. 323-343). PPS UIN Sunan Kalijaga Yogyakarta.

Nurlitasari, A. D., Wiyani, C., \& Syafitri, E. N. (2019). Hubungan Peran Keluarga Dan Lingkungan Sosial Dengan Identitas Diri Transgender Di LSM Kebaya Yogyakarta. Jurnal Keperawatan Respati Yogyakarta, 6(3), 695-701.

Rokhmah, D. (2015). Pola Asuh dan Pembentukan Perilaku Seksual Berisiko Terhadap Hiv/Aids Pada Waria. KEMAS: Jurnal Kesehatan Masyarakat, 11(1), 125-134.

Rokhmah, D. (2017). Buku Pandauan Orang Tua: Strategi Pencegahan LGBT Pada Anak. Gosyen Publishing.

Saleh, S. (2017). Analisis Data Kualitatif. Pustaka Ramadhan.

Salman, D., \& Suardi. (2015). Pembentukan Identitas Kaum Waria Kecamatan Bulukumpa. Equilibrium: Jurnal Pendidikan, 3(1), 47-56.

Sinyo. (2014). Anakku bertanya tentang LGBT: Panduan lengkap orangtua Muslim tentang dunia LGBT. Quanta.

Sinyo. (2016). Lo Gue Butuh Tau LGBT. Gema Insani.

Suardi, N. \&. (2017). Relasi dan Perilaku Sosial Biseksual pada Waria di Kota Makassar. Jurnal Sosiologi USK (Media Pemikiran \& Aplikasi), 11(2), 153-166.

Suendri. (2016). Kontrol Orang Tua Terhadap Pencegahan Cyberbullying Pada Penggunaan Internet Bagi Anak Dalam Persfektif Islam. Dalam Strategi Pendidikan Anak Usia Dini dalam Membina Sumber Daya Manusia Berkarakter (hlm. 99-111). Perdana Publishing.

Sugianto, F. (2015). Economic Approach To Law. Prenada Media.

Wahyuni, D. (2018). Peran Orang Tua dalam Pendidikan Seks Bagi Anak untuk Mengantisipasi LGBT. Quantum: Jurnal Ilmiah Kesejahteraan Sosial, XIV(25), 23-32.

Yusran, Y. (2018). "Bissu" Bukan Waria (Studi Atas Hadis-Hadis Tentang Khuntsa). SOSIORELIGIUS, 3(1), 66-76. 